NBER WORKING PAPER SERIES

\title{
OLDER WOMEN'S LABOR MARKET ATTACHMENT, RETIREMENT PLANNING, AND HOUSEHOLD DEBT
}

\author{
Annamaria Lusardi \\ Olivia S. Mitchell \\ Working Paper 22606 \\ http://www.nber.org/papers/w22606 \\ NATIONAL BUREAU OF ECONOMIC RESEARCH \\ 1050 Massachusetts Avenue \\ Cambridge, MA 02138 \\ September 2016
}

The authors thank Julie Agnew, Claudia Goldin, Larry Katz and participants at the 'Women Working Longer' conference for comments, and Noemi Oggero and Yong Yu for expert programming and research assistance. Research support was provided by the TIAA Institute and the Pension Research Council/Boettner Center at the Wharton School of the University of Pennsylvania. Opinions and conclusions expressed herein are solely those of the authors and do not represent the opinions or policy of the funders or any other institutions with which the authors are affiliated. The views expressed herein are those of the authors and do not necessarily reflect the views of the National Bureau of Economic Research.

At least one co-author has disclosed a financial relationship of potential relevance for this research. Further information is available online at http://www.nber.org/papers/w22606.ack

NBER working papers are circulated for discussion and comment purposes. They have not been peer-reviewed or been subject to the review by the NBER Board of Directors that accompanies official NBER publications.

(C) 2016 by Annamaria Lusardi and Olivia S. Mitchell. All rights reserved. Short sections of text, not to exceed two paragraphs, may be quoted without explicit permission provided that full credit, including $\odot$ notice, is given to the source. 
Older Women's Labor Market Attachment, Retirement Planning, and Household Debt Annamaria Lusardi and Olivia S. Mitchell

NBER Working Paper No. 22606

September 2016

JEL No. D91,J14

\begin{abstract}
$\underline{\text { ABSTRACT }}$
The goal of this paper is to ascertain whether older women's current and anticipated future labor force patterns have changed over time, and if so, to evaluate the factors associated with longer work lives and plans to continue work at older ages. Using data from both the Health and Retirement Study (HRS) and the National Financial Capability Study (NFCS), we show that older women's current and intended future labor force attachment patterns are changing over time. Specifically, compared to our 1992 HRS baseline, more recent cohorts of women in their 50's and 60s's are more likely to plan to work longer. When we explore the reasons for delayed retirement among older women, factors include education, more marital disruption, and fewer children than prior cohorts. But household finances also play a key role, in that older women today have more debt than previously and are more financially fragile than in the past. The NFCS data show that factors associated with retirement planning include having more education and greater financial literacy. Those who report excessive amounts of debt and are financially fragile are the least financially literate, had more dependent children, and experienced income shocks. Thus shocks do play a role in older women's debt status, but it is not enough to have resources: people also need the capacity to manage those resources if they are to stay out of debt as they head into retirement.
\end{abstract}

\author{
Annamaria Lusardi \\ The George Washington University \\ School of Business \\ 2201 G Street, NW \\ Duques Hall, Suite 450E \\ Washington, DC 20052 \\ and NBER \\ alusardi@gwu.edu \\ Olivia S. Mitchell \\ University of Pennsylvania \\ The Wharton School \\ 3620 Locust Walk, St 3000 SH-DH \\ Philadelphia, PA 19104-6302 \\ and NBER \\ mitchelo@wharton.upenn.edu
}




\title{
Older Women's Labor Market Attachment, Retirement Planning, and Household Debt
}

\author{
Annamaria Lusardi and Olivia S. Mitchell
}

Economic research has shown convincingly that young and middle-aged women's attachment to the paid labor force has risen substantially over time in America. ${ }^{1}$ To examine whether this pattern might also characterize older women, this paper examines several cohorts of older women in the Health and Retirement Study (HRS) to document the size of possible future changes, and to pinpoint which groups might be most likely to extend their work lives. In addition, we investigate what role debt might play in older women's continued work. For this we examine the 2012 National Financial Capability Study (NFCS), which provides detailed information on how older women appear to be managing their debt and their retirement planning efforts. Our focus throughout is on descriptive analysis rather than proving causal links between retirement and debt.

Our findings from the HRS show that recent cohorts of older women were more likely to be working at both ages 51-56 and 57-61 than the earliest cohort of the same age, first surveyed in $1992 .^{2}$ Effects differ significantly over time, in that the mean probability of being at work for the baseline HRS sample age 51-56 when surveyed was 64.9 percent, and 54.8 percent for those age 57-61. All subsequent cohorts displayed higher rates of work, particularly for the age 51-56 cohort, controlling for other factors. Thus, there is a rising probability of working among older women across cohorts.

\footnotetext{
${ }^{1}$ See for instance Goldin (2006; 2014) and the citations included therein.

2 The 51-56 age cohorts of women were surveyed in 1992 (the HRS baseline group, born 19361941), the 1998 War Babies (WB) group (born 1942-1947), the 2004 Early Baby Boomers (EBB) cohort (born 1948-1953), and the 2010 Middle Baby Boomer (MBB) group (born 19541959). The three 57-61 age cohorts of women were surveyed in 1992 for the baseline HRS cohort, in 2004 for the WBB; and in 2010 for the EBB.
} 
We also find that recent cohorts of women drawing near to retirement have more debt than before, and this is positively associated with older women being more likely to work currently, as well as to plan to continue to work in the future. Somewhat surprisingly, total debt more than doubled in constant dollars, and older women were increasingly likely to hold mortgage debt in excess of half their residential value in recent waves. Additionally, the percentage of women having less than $\$ 25,000$ in savings for recent cohorts is roughly double that of the earlier cohorts.

We also draw on data from the 2012 NFCS to explore the factors associated with retirement planning, debt and debt management, and an indicator of financial fragility. As shown in previous work, planning for retirement is associated with better retirement security (Lusardi and Mitchell 2007a, 2011a, 2014). Moreover, many people are found to pay high interest and fees on the debt they carry, and debt is part of household balance sheets throughout the lifetime and even close to retirement (Lusardi and Tufano, 2015; Lusardi and Mitchell, 2013). Correlates of retirement planning include having higher income, more education, and greater financial literacy for both age groups we evaluate (age 51-56 and 57-61). Factors associated with overindebtedness and financial fragility include lower financial literacy, having more financially dependent children, and experiencing unexpected and large income declines. Accordingly, shocks do play a role in the accumulation of debt close to retirement. Nevertheless, it is not enough to have resources: people also need the capacity to manage those resources if they are to stay out of debt and find retirement security at older ages. 


\section{Prior Studies}

Many prior studies have explored American women’s labor supply patterns over time (c.f., Goldin, 2006; Attanasio, Low, and Sanchez-Marcos, 2008; Michaud and Rohwedder, 2015). Yet there has been relatively little work focusing on cohort changes in older women's participation patterns and debt, as well as financial literacy. In this section we review relevant literature on these issues.

Several authors have evaluated the links between debt management and financial literacy, and they have concluded that the least financially literate incurred high fees and used high-cost borrowing. The least financially knowledgeable also report that their debt loads were excessive and they were often unable to judge their debt positions (Lusardi and Tufano, 2015, and the references therein). This group was also more likely to borrow from their 401(k) and pension accounts (Lu, Mitchell, and Utkus, 2010; Utkus and Young, 2011) and use high-cost methods of borrowing, such as payday loans (Lusardi and de Bassa Scheresberg, 2013).

There has been some research linking the quality of financial decision making and age, and the findings offer little reason for complacency. For instance, one influential study (Agarwal et al., 2009) found that the quality of financial decision making fell at an older age in 10 financial areas, including credit card balance transfers; home equity loans and lines of credit; auto loans; credit card interest rates; mortgages; small-business credit cards; credit card late-payment fees; credit card over-the-limit fees; and credit card cash-advance fees. Older persons pay higher financial service fees and interest.

In the wake of the financial crisis, these age-linked patterns are now translating into an awareness that older Americans are nearing retirement with increasingly concerning levels of 
debt. ${ }^{3}$ For instance debt held by borrowers age 50-80 rose roughly 60\% between 2003 and 2015, while aggregate debt balances held by younger borrowers declined modestly (Brown et al., 2016). Much of this rise consisted of home mortgages, held by over half (55\%) of the American population age 55-64, and about the same fraction (50\%) had credit card debt (Bucks et al., 2009). Moreover, among people age 65-74, two-thirds held some form of debt, almost half had mortgages or other loans on their primary residences, over one-third held credit card debt, and a quarter had installment loans. In recent years, on average, older borrowers held substantially more debt than did borrowers of the same age in the 1990s: for instance Lusardi and Mitchell (2013) showed that the percentage of people age 56-61 having debt swelled to $71 \%$ in 2008, up from $64 \%$ in 1992. Additionally, the value of their debt rose sharply over time. Median household debt in 1992 was about $\$ 6,200$, but by 2002 it had more than tripled. By 2008, it was \$28,300—more than quadruple the 1992 level.

Accompanying this trend has been an increase in the proportion of older Americans filing for bankruptcy over time: people age 65+ are the fastest-growing group in terms of bankruptcy filings, which stood at 2\% in 1991 and rose to over three times that rate by 2007 (Pottow, 2012). Credit card interest and fees were the most-cited reason for bankruptcy filings by older people, with two-thirds of them providing this reason. ${ }^{4}$ Moreover, there is also a continuing tendency of

\footnotetext{
${ }^{3}$ For a few recent examples, see AARP (2013), Cho (2012), Copeland (2013), Pham (2011), Securian (2013), Lusardi and Mitchell (2013), and the references therein.

${ }^{4}$ Other data sources confirm these findings. People age 55+ hold widespread credit card debt and pay a great deal in fees for late payments and exceeding credit limits, and this at a time when they should be at the peak of their wealth accumulation process (Lusardi, 2011; Lusardi and Tufano, 2015). Data from the 2012 National Financial Capability Study highlighted that 60\% of pre-retirees had at least one source of long-term debt, and $26 \%$ had at least two. Nearly $40 \%$ of pre-retirees used credit cards expensively, and the same percentage felt heavily indebted (Lusardi and de Bassa Scheresberg, 2014). Other surveys suggest similar conclusions. The 2013 Survey of Consumer Finances showed that family net worth-the difference between families' gross assets and their liabilities - generally increases with age, with a plateau or modest decreases for the
} 
women filing for bankruptcy more often than men, and women report being overextended on credit as the key reason for filing (Institute for Financial Literacy, 2011).

Another key factor spurring the increase in debt over time has been the much higher prices paid by recent cohorts for housing, and their resulting larger residential mortgages. For example, the median amount older homeowners owed on mortgages increased 82 percent from approximately $\$ 43,400$ in 2001 to $\$ 79,000$ in 2011. Further, data show older consumers owe more on their mortgages in relation to the value of their homes than their peers did a decade ago. The outstanding balance on their mortgages relative to the value of their homes (debt-to-value ratio) increased from 30 percent to 46 percent between 2001 and 2011 (CFPB, 2014). Until 2009, single women — the fastest growing segment of the housing market—purchased more homes than single men. Since, on average, women pay more for their mortgages than do men, it is unsurprising that mortgage debt is reported to be especially high among older women (Drew, 2006; Clark, 2015; Cheng, Lin, and Liu, 2011).

A related point is that subprime mortgage lenders targeted minority, elderly, and female buyers in the years leading up to the financial crisis. Prior to the financial crisis, female homebuyers were 32 percent more likely to have subprime mortgage loans, despite having higher credit scores on average (U.S. Congress Joint Economic Committee, 2008). These mortgages, which made up only 13 percent of all home loans but accounted for 55 percent of foreclosure starts, left older Americans vulnerable, and when housing prices sharply declined many turned to delinquency (Leland, 2008). This led to a fivefold rise in the serious delinquency rate between

oldest age groups relative to the near-retirement age groups (Bricker et al., 2014). The median net wealth of near retirees (households headed by someone between the ages of 55 and 64) was lower in 2013 than in 1989 (Rosnick and Baker, 2014). 
2001 and 2011 for mortgage holders age 65-74 (CFPB, 2014), underscoring the risk of holding such high levels of debt at older ages.

There is also evidence that rapid changes in housing prices altered older Americans' labor market attachment. For example, Begley and Chan (2015) explored the relationship between unanticipated changes in housing wealth, such as those experienced during the Great Recession, and retirement behavior by examining how the variation in the timing of housing price influenced work effort. They showed that women experiencing large negative housing price shocks were $25 \%$ less likely to retire relative to those experiencing positive shocks. Moreover, homeowners having mortgages were less likely to retire (if not yet retired) or more likely to reverse retirement (if already retired). Farnham and Sevak (2016) found that people responded to rising home prices by revising down their expected retirement ages. Specifically, they estimated that a $10 \%$ real increase in home value reduced expected retirement ages by about four months. One might anticipate that the mechanism worked in reverse when housing prices fell during the financial crisis and thereafter.

The trend in debt is attracting increasing attention from the media, with recent articles exhorting people to cut their debt as they near retirement (e.g., Derousseau, 2016). Additionally the high and rising levels of household debt are increasingly troubling older persons as well (FINRA, 2006, 2007; United States Government Accountability Office, 2015). For instance just 9\% of workers in 2016 who described their debt as a major problem said they were very confident of having enough money to live comfortably throughout retirement. Yet retirement saving efforts are still lagging, according to the 2016 Retirement Confidence Survey (RCS) 
(Blakely, VanDerhei, and Copeland, 2016). Instead, people who admitted they were undersaving indicated that they would likely cope with the shortfall by either saving more or working longer. ${ }^{5}$

In what follows we contribute to the literature by examining cohort changes in older women's work plans and debt burdens using the HRS, as well as the links between financial literacy and debt stresses in the NFCS. Our results point to the need for boosting older women's retirement security and the important role of managing debt later in life.

\section{Cohort Trends in Continued Work and the Role of Debt in the HRS}

In this section we analyze distinct cohorts of older women observed in the HRS, a nationally representative survey of respondents over the age of 50. Specifically, we focus on four birth cohorts of women first surveyed when age 51-56, and three cohorts of women surveyed when age 57-61, so as to evaluate each of them on the verge of retirement. We utilize extensive information gathered by the HRS about these women's current employment status and future work plans, along with their sociodemographic characteristics, including marital and family histories. In so doing, we evaluate whether there are statistically significant differences across the cohorts after controlling for other factors. We also evaluate whether these factors are correlated with anticipated future work. Finally, we evaluate the extent to which the older women's cohorts differ with regard to how much debt they held as they entered their 50's. This permits us to evaluate whether rising levels of debt might be significantly associated with plans to continue working at older ages.

\section{Cohort Differences}

${ }^{5}$ This is somewhat worrisome since some retirees indicate that they could not work longer because they were forced to leave the workforce earlier than planned (for reasons such as health problems or disability) (Banerjee, 2014). 
For the cohort analysis, we examine four groups of women initially surveyed when they were age 51-56, and three different groups age 5761. This is facilitated by the structure of the HRS (see Figure 1), which periodically enrolls refresher cohorts over time. For the age 51-56 group, we include those first surveyed in 1992 (the HRS baseline group, born 1936-1941), the 1998 War Babies (WB) group (born 1942-1947), the 2004 Early Baby Boomers (EBB) cohort (born 1948-1953), and the 2010 Middle Baby Boomer (MBB) group (born 1954-1959). The three 57-61 age cohorts of women were surveyed in 1992 for the baseline HRS cohort, in 2004 for the WB; and in 2010 for the EBB. ${ }^{6}$

Figure 1 here

Our empirical modeling in each case involves multivariate analysis of each respective outcome variable $(y)$ on a vector of cohort dummies, where the HRS baseline is the reference category. The main outcomes analyzed are an indicator of the respondents' current employment status, and their estimated chances of working at age 65. In both cases, the estimated coefficients on the cohort dummies refer to the differential behavior of subsequent cohorts versus the HRS baseline 1992 cohort. In all cases we control for the respondent's age, race (White vs other), and ethnicity (Hispanic vs other). These factors are, of course, most likely to be exogenous to past work patterns. We also control for the respondent's years of education, whether she had experienced marital disruption (ever divorced or widowed), whether she was in fair or poor health, her number of children, and ratios of her household primary residence and other debt to, respectively, housing value and liquid assets. These factors permit us to ascertain whether what might appear to be cohort differences could instead be associated with differences in socioeconomic and demographic factors over time, including changes in financial markets and the

\footnotetext{
${ }^{6}$ Descriptive statistics for our sample appear in Appendix 1.
} 
increased opportunities to borrow and take on debt. The entire sample includes slightly over 6,700 women age 51-56 and around 4,200 women age 57-61.

Our first set of results examines whether women reported working for pay at the time of their interview, and Table 1 reports coefficient estimates of the linear probability analysis. Panel A provides results for current work among the women age 51-56 when surveyed, while Panel B looks at the same outcomes for the older age 57-61 groups. For both age groups, the first column excludes debt to asset ratio variables, while the second two includes them to allow comparison of results.

\section{Table 1 here}

Looking across the first three rows of coefficient estimates it is clear that, compared to the first HRS baseline group, recent cohorts of women were increasingly likely to be working in their 50's. The mean probability of being at work for the baseline HRS sample age 51-56 when surveyed was 64.9 percent, and 54.8 percent for those age 57-61. All subsequent cohorts displayed higher rates of work, particularly for the age 51-56 cohort. For instance, younger WB women age 51-56 had about a 7 percentage point greater labor force attachment, or around 11\% higher than the HRS reference cohort. Early Boomer women age 51-56 were 5.3-5.7 percentage points more attached to the labor force, or 8\% more than the HRS, while the older group (age 57-61) of Early Boomers had participation rates of 4.7-6.2 percentage points higher, or 8-11\% more than the HRS reference group. The younger Middle Boomers also were working more than the reference group, with 3.8-4.5 percentage point greater employment rates, or 6-7\% versus the HRS reference cohort. 
The measured effects are also robust to the inclusion or exclusion of the financial variables, as are virtually all of the other coefficient estimates. ${ }^{7}$ In other words, these estimates confirm that the probability of working rose across the cohorts compared to the HRS baseline. Nevertheless, the magnitudes were somewhat larger for the younger WB group, a bit less for the Early Boomers, and smallest (though still statistically significantly different from zero) for the MBB age group. Among the older women, the Early Boomers were substantially more likely to be working compared to the baseline HRS.

Turning to Table 2, we see that among the HRS cohort, 22.5 percent of the younger age group (51-56) and 23.4 of the older age group intended to still work at age 65. Interestingly, there is no significant difference between the HRS cohort and the War Babies in terms of the women's plans to continue working, but both Boomer cohorts were significantly more likely to say they intended to work at age 65 , compared to the original HRS cohort. ${ }^{8}$ Moreover, intentions to work at age 65 rose over time. That is, the age 51-56 Early Boomers were about 3.6-3.7 percentage points (or 16\%) more likely to work at age 65, where the Middle Boomers were 7.7-7.9 percentage points (or 35\%) more likely to plan to work longer, compared to the benchmark. For the older group (age 57-61) the increase was similar in percentage points (4.75.1) but as it was measured on a slightly higher base, the $20 \%$ increase was slightly lower. In any case, the most recent cohorts for which we have data appear to be notably more attached to the labor force into their mid-60's. As before, comparing Panels A in Tables 1 and 2, we again see

\footnotetext{
${ }^{7}$ In results not detailed here, we have explored additional models where we interacted the debt variables with marital disruption to test whether including these terms alters the estimated cohort effects. Doing so does not change conclusions reported in the text.

${ }^{8}$ The reader is reminded that the question about chances of working at age 65 was asked only of those working when surveyed at a younger age.
} 
that the magnitudes of the cohort effects are relatively invariant to including additional controls. ${ }^{9}$ Therefore little of what we have attributed to cohort differences is associated with more recent waves of older women having more education, higher rates of marital disruption, and fewer children.

Table 2 here

Impacts of Other Factors

We also seek to analyze the impact of other factors on women’s current and future work patterns. Looking across Tables 1 and 2, we see that age is generally negative when statistically significant, indicating that even within these narrow age bands, older women's labor market attachment does decline. Nevertheless the estimated age coefficients are only weakly significant in Table 2 across the board, and not significant for the younger women in Table 1. Thus older women's workforce attachment does not decline in lockstep with age, by any means. Another factor consistently significant and positively associated with work is years of educational attainment, such that one more year of schooling is associated with a 3 percentage point higher probability of women's current work (Table 1), and a 0.8-1.1 percentage point higher chance of working at age 65 (Table 2). Interestingly, women who were widowed or divorced (marital disruption) are 6-8 percentage points more likely to be working currently, and they have an 8-9 percentage point greater expectation of working at age 65. Poor health is quite important in terms of explaining work patterns for both age groups: those in fair/poor health were 28-30 percentage points less likely to be working, and among workers, 10-14 percentage points less likely to project that they would still be working at age 65. Accordingly, women in good health or better

\footnotetext{
${ }^{9}$ In results not detailed here we have also explored models where we interacted the debt variables with marital disruption to test whether including these terms alters the estimated cohort effects. Doing so does not change conclusions reported in the text.
} 
are much more likely to report they will remain employed at age 65. Finally, the number of children has a significant negative effect on older women's current employment but only for the 51-56 age group, and the impact is small (-0.9 percentage points).

\section{What Role for Debt?}

The last two rows of Tables 1 and 2 speak to the question of how debt is associated with older women’s work patterns, a topic of substantial current interest (Lusardi and Mitchell, 2013). Our findings indicate that mortgage debt, in particular, is associated with a higher probability of women working for pay and expecting to be working at age 65. For instance, an increase of a standard deviation in the ratio of mortgage debt to home value ${ }^{10}$ in Table 1 is associated with a 3.4 percentage point rise (or 5\%) in younger women's anticipated probability of working at age 65. This is in line with Fortin (1995), who suggested that liquidity constraints related to home down payments prompted many women to work more. The effect we discern here is complimentary, suggesting that older women may defer retirement due to the need to help repay their mortgage debt. The effect is even larger, at 5.5 percentage points (or $10 \%$ ), for the 57 - to 61-year-old group. The second debt variable we included in the model, the ratio of nonmortgage debt to liquid assets, is generally small and not statistically significant across Tables 1 and 2.

To further examine the role of debt, we note that previous research has reported that people are reaching retirement age today holding more debt than in the past. ${ }^{11}$ Accordingly, we devote some additional attention to various measures of older women's debt and financial fragility across cohorts in Table 3.

\section{Table 3 here}

${ }^{10}$ A standard deviation in the ratio of all primary residential loans to primary residence value is equal to 0.54 for the age 51-56 group, and 0.62 for those age 57-61.

${ }^{11}$ See, for instance, Lusardi and Mitchell (2013); AARP (2013); Bucks et al. (2009); Butrica and Karamcheva (2013); Copeland (2013), and Pottow (2012). 
Results show that Baby Boomer cohorts are more likely to have debt later in life for both age groups (51-56 and 57-61) compared to the baseline HRS cohort (Panel 1). Moreover, recent cohorts have higher levels of total debt late in life (Panel 2). It is also striking that cohort mean and median debt levels have been steadily rising over time. For example, while the median (p50) debt of the HRS baseline was a little more than $\$ 15,000$ for women age $51-56$, this level almost tripled for the Middle Baby Boomers (\$43,200; all values are in \$2015). Increases in debt are even more striking for the older group of women age 57-61: the EBB cohort had almost eight times as much debt as the baseline HRS cohort (\$31,320 versus \$4,175).

One reason for such a large expansion in debt is that households have taken on larger mortgages in recent years. This is the pattern we observe for both of the age groups we examine (Panel 3 of Table 3). Mortgages, along with loans related to the primary residence, not only grew in absolute value but they also rose as a percentage of the value of the primary residence. These ratios more than doubled for the older respondents: while the older HRS baseline cohort (age 5761) neared retirement with a ratio of mortgages and loans on the value of the primary residence of 0.11 , this ratio grew to 0.28 for the Early Boomers. Moreover, older women are more likely to be in households where the ratio of mortgage debt to residential value has doubled, from $18 \%$ to 32\%, comparing the Middle Boomers to the HRS baseline cohort. This implies that many older women will need to manage mortgage debt well into their older years, consistent with the findings reported by Lusardi and Mitchell (2013). In other words, during retirement, Boomer cohorts will have to use their income and assets to repay debt, in contrast to the earlier cohort.

And even more striking is the fact that higher proportions of older women are in financially fragile circumstances compared to two decades ago. Only $18 \%$ of the younger HRS 
cohorts had less than $\$ 25,000$ in savings, ${ }^{12}$ whereas one-third of the MBB group reported having so little savings (Panel 4). We conclude that higher debt levels in later life could well be contributing to rising labor force attachment among older women.

\section{Financial Frailty at Older Ages: Findings from the NFCS}

To further explore how older women are managing their debt and retirement planning, we draw on the 2012 wave of the National Financial Capability Study (NFCS). ${ }^{13}$ The overarching research objectives of the NFCS are to benchmark key indicators of financial capability and evaluate how these indicators vary with underlying demographic, behavioral, attitudinal and financial literacy characteristics. ${ }^{14}$ The 2012 NFCS is a state-by-state online survey of approximately 25,000 American adults (roughly 500 per state, plus the District of Columbia) that is representative of the U.S. population. ${ }^{15}$ In order to thoroughly explore the financial capability of Americans, the NFCS covers several aspects of behavior, including how people manage their resources, how they make financial decisions, what skill sets they use in making these decisions, and how they search for information when making these decisions (Lusardi, 2011).

Consistent with the HRS analysis above, we again focus on two separate age groups of women in the NFCS: age 51-56 and age 57-61. There are over 1,800 observations for the first

\footnotetext{
${ }^{12}$ Savings is defined as total net worth or total assets minus total debt.

13 The data are publicly available at http://www.usfinancialcapability.org/ The first survey was fielded in 2009, and it is slated to be repeated triennially.

${ }^{14}$ FINRA Investor Education Foundation commissioned the NFCS in 2009 in consultation with the U.S. Department of the Treasury and the President's Advisory Council on Financial Literacy. The 2012 Study - similarly developed in consultation with the U.S. Department of the Treasury, other federal agencies, and President Obama's Advisory Council on Financial Capabilityupdated key measures from the 2009 Study and deepened the exploration of topics that are highly relevant for research and policy. Lusardi serves as academic advisor to the Study.

${ }^{15}$ In our analysis, data are weighted to be representative of the national population as a whole in terms of age, gender, ethnicity, and education, based on the Census Bureau's American Community Survey. However, breakdowns of sub-populations may not necessarily be representative.
} 
age group and around 1,300 for the second. The empirical analysis evaluates whether older women tried to figure out how much they need to save for retirement, their perceived level of indebtedness, and their financial fragility, which relies on respondent answers to whether they could come up with $\$ 2,000$ in 30 days if an unexpected need arose. ${ }^{16}$

To this end, Table 4 displays descriptive statistics for women age 51-56 in Panel A, and for women 57-61 in Panel B. Here we see that the sample is mostly married, white, working, and has at least some college education. The older women (57-61) indicated they were more likely to plan for retirement (or to have planned, if they had retired), but fewer than half (45\%) had tried to figure out how much they needed to put aside for retirement, versus 39\% of women age 5156. Moreover, many of them indicate they are carrying too much debt (43\% of those age 51-56 and $39 \%$ of those age 57-61) and that they are financially fragile (43\% of the younger and 39\% of the older group). This is consistent with the HRS evidence showing high levels of debt on the verge of retirement.

\section{Table 4 here}

Other indicators of financial distress are reported in Table 5. Results show that about a third of women (age 51-56) are able to easily cover their expenses in a typical month, or have set aside emergency or rainy day funds that would cover expenses for three months. NFCS data

16 The precise wording of the questions are (1) Retirement planning: Have you ever tried to figure out how much you need to save for retirement? Or, if already retired: Before you retired, did you try to figure out how much you needed to save for retirement? Possible answers: yes, no, don't know, prefer not to say. (2) Debt: How strongly do you agree or disagree with the following statement: I have too much debt right now. Please give your answer from a scale from 1 to 7, where 1=strongly disagree, 7=strongly agree and 4=neither agree nor disagree. Possible answers: 1-7; don't know, prefer not to say. (3) Financial fragility: How confident are you that you could come up with $\$ 2000$ if an unexpected need arose within the next month? Possible answers: I am certain I could come up with the full \$2,000, I could probably come up with $\$ 2,000$, I could probably not come up with $\$ 2,000$, I am certain I could not come up with $\$ 2,000$, don’t know, prefer not to say. 
confirms that mortgage debt and other debts turn out to be problematic for a relatively large subset of women. Twenty percent of the female homeowners in the younger age group and 15 percent in the older age group report being underwater, owing more on their homes than they thought they could sell them for. As far as non-mortgage debt is concerned, many women said they did not pay off credit card balances in full (if they had them), and they engaged in many costly credit card behaviors such as paying only the minimum due, using the card for cash advances, being charged fees for late payment, or exceeding the limits. These findings underscore the point that many older women are exposed to illiquidity and/or problems in debt management. Turning to other indicators, many older women reported having unpaid medical bills, and having engaged in high-cost borrowing using alternative financial services, such as rent-to-own stores, pawn shops, payday loans, auto title loans, and tax refund loans.

\section{Table 5 here}

The NFCS also included a set of questions to assess respondents' levels of financial literacy. Five questions were asked to test fundamental concepts regarding numeracy and the capacity to do calculations related to interest rates, knowledge of inflation, risk diversification, understanding of interest payments on a mortgage, and understanding of basic asset pricing (Lusardi, 2011). Table 6 reports the proportion of correct and incorrect answers and the "do not know" responses to each of these questions. Overall, we find that financial literacy is rather low. A large fraction of women does not know simple financial concepts, and many indicate that they do not know the answer to the questions. The proportion of "do not know" responses was particularly high on the risk diversification question; as many as 52\% of women age 51-56 and $51 \%$ of women age 57-61 indicated that they did not know whether a single company stock is riskier than a stock mutual fund. There is also a high proportion of "do not know" responses for 
the question on asset pricing. These two questions will help us differentiate among different degrees of financial literacy among older women.

Table 6 here

Multivariate Regression Analysis

Next we present multivariate linear probability analyses of indicators of financial planning, debt, and financial fragility. For the first dependent variable, we use the NFCS question about whether respondents ever tried to figure out how much they need to save for retirement. This is an important question in light of prior research showing that planners accumulate far more retirement wealth than non-planners (Lusardi, 1999; Lusardi and Beeler, 2007; Lusardi and Mitchell, 2007a, b; 2011a, b). In addition to the regressors used in the HRS analysis, namely age and ethnicity, we also control for marital status, education, income (using dummies), and number of children. In addition, the richness of the NFCS allows us to control for whether respondents experienced a large and unexpected drop in income the previous year, and also the respondent's level of financial literacy (defined as the number of correct answers to the five financial literacy questions). Results are reported in the first column of Table 7.

\section{Table 7 here}

Both Panels A and B in Table 7 confirm that higher education and income are strongly positively correlated with women having tried to figure out how much to save for retirement among both age groups. Their number of dependent children is negatively associated with the probability of having tried to plan for women age 51-56 but not for the older group, suggesting some potential for a 'catch-up’ after children leave home. Interestingly, financial literacy is also an important determinant of financial planning: being able to answer one additional financial literacy question correctly is associated with a 4-6 percentage point higher probability of 
figuring out how much to put aside for retirement. This is a reasonably large result, in view of the fact that only $39-45 \%$ of the respondents indicated they had tried to plan for retirement (Table 4). This finding is consistent with data from the 2009 wave of the NFCS (Lusardi and Mitchell, 2011b) where we use a very similar empirical specification, but we use all respondents and all age groups, and other surveys as well that use different measures of planning (Lusardi and Mitchell, 2014). This finding is also consistent with data from a special module we designed for the HRS on retirement planning and financial literacy; in that work we showed that financial literacy is an important predictor of retirement planning for older women as well (Lusardi and Mitchell, 2008).

Next we turn to respondents' answers to the NFCS question about their degree of agreement with the statement: "I have too much debt right now." We use this variable to proxy for peoples' concerns about their debt, since debt levels (as reported in the HRS) are not available in the NFCS. Results are reported in column (2) of Table 7 for both age groups (Panels A and B).

Once again, we find that women who report having too much debt are also those with more dependent children, with the effect among the older age group almost three times as large as for those age 51-56. Shocks also matter: those having had a large unexpected income drop in the prior year were 68-78 percentage points more likely to state that they were over-indebted. Those with higher income (income greater than \$100,000 for women age 51-56 and income greater than $\$ 150,000$ for women age $57-61$ ) are less likely to have too much debt. And once again, the more financially literate were less likely to report they had excessive debt (answering one more financial literacy question decreases the probability of "too much debt" by 8-10 percentage points), confirming findings in other surveys and other age groups (Lusardi and 
Tufano, 2015). In other words, shocks do contribute to debt concerns for women on the verge of retirement, but people who have the capacity to manage their resources are more likely to stay out of debt as they head into retirement.

The financial fragility measure available in the NFCS is a proxy for low savings. While the HRS reports whether women have less than $\$ 25,000$ in savings, the NFCS asks if they could come up with $\$ 2,000$ within a month (multiplying that figure by 12 would bring $\$ 24,000$ ). Findings in column (3) of Table 7 show that, for both age groups, having more dependent children and having experienced an income shock are positively and significantly associated with the probability of being financially fragile. Those with higher income are less likely to be financially fragile. Moreover, those who are more financially literate have a lower probability of being financially fragile.

\section{Conclusions}

Our goal in this paper has been to ascertain whether older women's current and anticipated future labor force patterns have changed over time, and if so, to evaluate the factors associated with longer work lives and plans to continue work at older ages. We have also sought to evaluate debt and debt management as a factor spurring older women's continued work.

The analysis has yielded several findings. First, we show that each cohort of older women worked more currently, and intended to work more in the future, than our HRS baseline surveyed in 1992. The mean probability of being at work for the baseline HRS sample (age 51-56 when surveyed) was 64.9 percent, and 54.8 percent for those age 57-61. All subsequent cohorts displayed higher rates of work, particularly the age 51-56 cohort. For instance, younger WB women age 51-56 had about a 7 percentage point greater labor force attachment, or around $11 \%$ 
higher, than the HRS reference cohort. Early Boomer women age 51-56 were 5.3-5.7 percentage points more attached to the labor force, or $8 \%$ more than the HRS, while the older (age 57-61) Early Boomers had participation rates of 4.7-6.2 percentage points higher, or 8-11\% more than the HRS reference group. The younger Mid-Boomers also were working more than the reference group, with 3.8-4.5 percentage point greater employment rates, or 6-7\% versus the HRS reference cohort.

Second, when we compare differences in older women's self-reported expected chances of working at older ages, again we find evidence that more recent cohorts of older women anticipate working longer. For the baseline HRS cohort, 22.5\% of the younger age group and 23.4 of the older age group intended to still work at age 65. By contrast, both the Early and Middle Baby Boomer cohorts were significantly more likely to say they intended to work at age 65. Early Boomers believed they had a 4-5 percentage point higher chance of working than the HRS cohort (on a base of about 26\%), and the Middle Boomers were even more likely to be working for pay at age 65 compared to the HRS reference group. These patterns confirm that continued work and delayed retirement is becoming more prevalent for older women over time.

Third, when we explored the explanations for delayed retirement among older women, significant factors included education, marital disruption, health, and fewer children than prior cohorts. Yet household finances also appeared to be playing a key role, in that older women today have more debt than previously, and they are more financially fragile than in the past. As an example, we showed that a standard deviation increase in the ratio of mortgage debt to home value was associated with a 3.4-5.5\% rise in women's anticipated probability of working at age 65. In large part this can be attributed to having taken on larger residential mortgages due to the run-up in housing prices over time and decline in required down payments. 
Our results using the NFCS are compatible with the HRS results, but the richer set of questions asked in the NFCS add additional dimensions to the results. For instance we found that women who were more financially literate were more likely to plan for retirement, were less likely to have excessive debt, and were less likely to be financially fragile. Having more children and unexpected, large income shocks also played an important role. Overall, these findings speak to the important role of managing finances later in life, including debt.

Our work to date has been mainly descriptive rather than causal, but we are well aware that planning, saving, and retirement decisions are all made in a life-cycle context. Accordingly our future research will explore ways to identify how financial literacy, planning, and debt management can help drive decision making at older ages which can be conducive to retirement security. 


\section{References}

AARP. (2013). In the Red: Older Americans and Credit Card Debt. AARP Public Policy Institute Report. www.aarp.org

Agarwal, S., J. Driscoll, X. Gabaix, and D. Laibson. (2009). “The Age of Reason: Financial Decisions over the Lifecycle with Implications for Regulation.” Brookings Papers on Economic Activity: 51-101.

Attanasio, O. H. Low, and V. Sánchez-Marcos. (2008). “Explaining Changes in Female Labor Supply in a Life-Cycle Model.” American Economic Review. 98(4): 1517-1552

Banerjee, S. (2014). “The Gap between Expected and Actual Retirement: Evidence from Longitudinal Data.” EBRI Notes, November 35(11).

Begley, J. and S. Chan. (2015). "The Effect of Housing Wealth Shocks on Work and Retirement Decisions.” NYU Wagner Research Paper No. 2634284.

Blakely, S., J. VanDerhei and C. Copeland. (2016). "Retirement Confidence Stable, But Preparations Still Lag.” News from EBRI.

Bricker J., L. Dettling, A. Henriques, J.W. Hsu, K.B. Moore, J. Sabelhaus, J. Thompson and R.A. Windle. (2014). “Changes in U.S. Family Finances from 2010 to 2013: Evidence from the Survey of Consumer Finances.” Federal Reserve Bulletin September 2014 Vol. 100 No. 4. http://www.federalreserve.gov/pubs/bulletin/2014/pdf

Brown, M., D. Lee, J. Scally, K. Strair, and W. van der Klaauw. (2016). The Graying of American Debt. Liberty Street Economics.

Bucks, B., A. Kennickell, T. Mach, and K. Moore. (2009). "Changes in U.S. Family Finances from 2004 to 2007: Evidence from the Survey of Consumer Finances.” Federal Reserve Bulletin 95: A1-A55.

Butrica, B. and N. Karamcheva. (2013). “Does Household Debt Influence the Labor Supply and Benefit Claiming Decisions of Older Americans?” Working Paper, Urban Institute.

CFPB. (2014). "Snapshot of Older Consumers and Mortgage Debt” http://files.consumerfinance.gov/f/201405_cfpb_snapshot_older-consumers-mortgagedebt.pdf

Cheng, P., Z. Lin, Y. Liu. (2011). "Do Women Pay More for Mortgages?" Journal of Real Estate Finance and Economics: 43(4): 423-44. 
Cho, H. 2012. "Seniors Grow Old Under Debt.” The Baltimore Sun/New America Media. http://newamericamedia.org/2012/05/seniors-grow-old-under-debt.php

Clark, P. (2015). “Return of the Single Female Homebuyer.” Bloomberg.

http://www.bloomberg.com/news/articles/2015-12-28/return-of-the-single-femalehomebuyer

Copeland, C. 2013. “Debt of the Elderly and Near Elderly, 1992-2010.” EBRI Notes. February 34.

Derousseau, R. 2016. “3 Ways to Reduce Debt as You Near Retirement.” U.S. News.

Drew, R. B. 2006. "Buying for Themselves: An Analysis of Unmarried Female Home Buyers.” Joint Center for Housing Studies, Harvard University. Report.

Farnham, M., and P. Sevak. 2016. "Housing Wealth and Retirement Timing.” CESifo Economic Studies n. 62 (1): 26-46.

Financial Industry Regulatory Authority (FINRA). 2006. Investor Literacy and Fraud Susceptibility Survey Executive Summary. http://www.finra.org/Investors/ProtectYourself/AvoidInvestmentFraud/.

Financial Industry Regulatory Authority (FINRA). 2007. Senior Fraud Risk Survey. http://www.finra.org/Investors/ProtectYourself/AvoidInvestmentFraud/.

Fortin, N. (1995). “Allocation Inflexibilities, Female Labor Supply and Housing Assets Accumulation: Are Women Working to Pay the Mortgage?” Journal of Labor Economics. 13: 524-557.

Goldin, C. (2006). “The 'Quiet Revolution' That Transformed Women’s Employment, Education, and Family.” American Economic Review, Papers and Proceedings. (Ely Lecture), 96: 1-21.

Goldin, C. (2014). “A Grand Gender Convergence: Its Last Chapter.” American Economic Review. 104(4):1091-1119.

Institute for Financial Literacy. (2011). “2010 Annual Consumer Bankruptcy Demographics Report: A Five Year Perspective of the American Debtor.” http://ssrn.com/abstract $=1925006$

Leland, J. (2008). “Baltimore Finds Subprime Crisis Snags Women.” The NY Times. http://www.nytimes.com/2008/01/15/us/15mortgage.html 
Lu, T., O. S. Mitchell, and S. P. Utkus. (2010). “An Empirical Analysis of 401(k) Loan Defaults.” Financial Literacy Consortium Report to the SSA. September.

Lusardi, A. (1999). “Information, Expectations, and Savings for Retirement.” In Behavioral Dimensions of Retirement Economics, edited by Henry Aaron. Washington, D.C.: Brookings Institution Press and Russell Sage Foundation: 81-115.

Lusardi, A. (2011). “Americans’ Financial Capability.” NBER Working Paper 17103.

Lusardi, A., and J. Beeler. (2007). “Saving Between Cohorts: The Role of Planning” in B. Madrian, O. Mitchell, B. Soldo (eds.), Redefining Retirement. How Will Boomers Fare? Oxford: Oxford University Press, 271-295.

Lusardi, A, and C. de Bassa Scheresberg. (2013). “Financial Literacy and High-Cost Borrowing in the United States.” NBER Working Paper 18969.

Lusardi, A, and C. de Bassa Scheresberg. (2014). "Financial Capability Near Retirement: A Profile of Pre-Retirees.” Filene Research Institute, October.

Lusardi, A., and O. S. Mitchell. (2007a). "Baby Boomer Retirement Security: The Role of Planning, Financial Literacy and Housing Wealth.” Journal of Monetary Economics 54: 205-224.

Lusardi, A., and O. S. Mitchell. (2007b). "Financial Literacy and Retirement Preparedness: Evidence and Implications for Financial Education.” Business Economics: 35-44.

Lusardi, A., and O. S. Mitchell. (2008). "Planning and Financial Literacy: How Do Women Fare?” American Economic Review Papers and Proceedings 98(2): 413-417.

Lusardi, A., and O. S. Mitchell. (2011a). "Financial Literacy and Planning: Implications for Retirement Wellbeing.” In O. S. Mitchell and A. Lusardi, eds., Financial Literacy: Implications for Retirement Security and the Financial Marketplace. Oxford, UK: Oxford University Press: 17-39

Lusardi, A., and O. S. Mitchell. (2011b). "Financial Literacy and Retirement Planning in the United States.” Journal of Pension Economics and Finance 10: 509-525.

Lusardi, A. and O. S. Mitchell. (2013). “Debt and Debt Management among Older Adults.” Paper presented at the 15th Annual Joint Conference of the Retirement Research Consortium, Washington, D.C.

Lusardi, A. and O. S. Mitchell. (2014). "The Economic Importance of Financial Literacy: Theory and Evidence.” Journal of Economic Literature 52(1): 5-44. 
Lusardi, A., and P. Tufano. (2015). "Debt Literacy, Financial Experiences, and Overindebtedness.” Journal of Pension Economics and Finance 14(4): 329-365.

Michaud, P-C., and S. Rohwedder. (2015). “Forecasting Labor Force Participation and Economic Resources of the Early Baby Boomers.” MRRC Working Paper. University of Michigan.

Pham, S. (2011). “Retirements Swallowed by Debt.” New York Times. January 26. newoldage.blogs.nytimes.com/2011/01/26/retirements-swallowed-by-debt/

Pottow, J. (2012). “The Rise in Elder Bankruptcy Filings and Failure of U.S. Bankruptcy Law.” The Elder Law Journal 19: 220-257.

Rosnick, D., and D. Baker. (2014). “The Wealth of Households: An Analysis of the 2013 Survey of Consumer Finances.” Center for Economic and Policy Research.

Securian Financial Group. (2013). Retirement Time Bomb: Mortgage Debt. Securian Investments.

www.securiannews.com/sites/securian.newshq.businesswire.com/files/research/file/RetD ebtSummary-Apr2013-F78685-1_pod.pdf

United States Government Accountability Office. (2015). “Most Households Approaching Retirement Have Low Savings.” USGAO: Washington, D.C.

U.S. Congress Joint Economic Committee. (2008). "Women and their Families are being Squeezed.” http://www.jec.senate.gov/public/_cache/files/dd3a9c6d-c0b6-4f82-853d55f6c72743f5/sqeezedwomanupdate-91608.pdf

Utkus, S., and J. Young. (2011). “Financial Literacy and 401(k) Loans.” In O. S. Mitchell and A. Lusardi, eds. Financial Literacy: Implications for Retirement Security and the Financial Marketplace. Oxford, UK: Oxford University Press: 59-75. 
Table 1. Factors Associated with Older Women's Current Employment in the Health and Retirement Study (HRS)

\begin{tabular}{|c|c|c|c|c|}
\hline \multirow{3}{*}{ WB } & \multicolumn{2}{|c|}{ A. Women age 51-56 } & \multicolumn{2}{|c|}{ B. Women age 57-61 } \\
\hline & $0.072 * * *$ & $0.070 * * *$ & 0.028 & 0.017 \\
\hline & $(0.017)$ & $(0.017)$ & $(0.023)$ & $(0.024)$ \\
\hline \multirow[t]{2}{*}{ EBB } & $0.057 * * *$ & $0.053 * * *$ & $0.062 * * *$ & $0.047 * *$ \\
\hline & $(0.017)$ & $(0.017)$ & $(0.023)$ & $(0.023)$ \\
\hline \multirow[t]{2}{*}{ MBB } & $0.045 * *$ & $0.038 * *$ & & \\
\hline & $(0.018)$ & $(0.018)$ & & \\
\hline \multirow[t]{2}{*}{ Age } & -0.002 & -0.001 & $-0.029 * * *$ & $-0.027 * * *$ \\
\hline & $(0.004)$ & $(0.004)$ & $(0.007)$ & $(0.007)$ \\
\hline \multirow[t]{2}{*}{ White } & 0.009 & 0.008 & 0.039 & 0.037 \\
\hline & $(0.016)$ & $(0.016)$ & $(0.025)$ & $(0.025)$ \\
\hline \multirow[t]{2}{*}{ Hispanic } & 0.026 & 0.026 & -0.008 & -0.002 \\
\hline & $(0.024)$ & $(0.024)$ & $(0.038)$ & $(0.038)$ \\
\hline \multirow[t]{2}{*}{ Years of Education } & $0.026 * * *$ & $0.025 * * *$ & $0.032 * * *$ & $0.032 * * *$ \\
\hline & $(0.003)$ & $(0.003)$ & $(0.004)$ & $(0.004)$ \\
\hline \multirow[t]{2}{*}{ Marital Disruption } & $0.081 * * *$ & $0.086 * * *$ & $0.065 * * *$ & $0.068 * * *$ \\
\hline & $(0.015)$ & $(0.015)$ & $(0.022)$ & $(0.022)$ \\
\hline \multirow[t]{2}{*}{ Fair/Poor Health Self-reported } & $-0.301 * * *$ & $-0.301 * * *$ & $-0.287 * * *$ & $-0.282 * * *$ \\
\hline & $(0.019)$ & $(0.019)$ & $(0.024)$ & $(0.024)$ \\
\hline \multirow[t]{2}{*}{ Number of Children } & $-0.009 * *$ & $-0.009 * *$ & -0.003 & -0.005 \\
\hline & $(0.004)$ & $(0.004)$ & $(0.005)$ & $(0.005)$ \\
\hline \multirow[t]{2}{*}{ All 1ry Res Loans/1ry Res. Value } & & $0.063 * * *$ & & $0.089 * *$ \\
\hline & & $(0.022)$ & & $(0.035)$ \\
\hline \multirow[t]{2}{*}{ Other debt/liquid assets } & & $0.001 *$ & & $(0.001)$ \\
\hline & & $(0.000)$ & & $(0.001)$ \\
\hline $\mathrm{N}$ & 6,677 & 6,677 & 4,160 & 4,160 \\
\hline R-square & 0.107 & 0.112 & 0.104 & 0.108 \\
\hline Mean of dep var & 0.709 & & 0.607 & \\
\hline St.dev of dep var & 0.454 & & 0.488 & \\
\hline Mean of dep var, HRS only & 0.649 & & 0.548 & \\
\hline St.dev of dep var, HRS only & 0.477 & & 0.498 & \\
\hline
\end{tabular}

Note: ${ }^{*} \mathrm{p}<0.10,{ }^{* *} \mathrm{p}<0.05,{ }^{* * *} \mathrm{p}<0.01$

Coefficient estimates from linear probability analysis, standard errors in parentheses. Controls for missing values included where relevant. The 51-56 age cohorts of women were surveyed in 1992 (the HRS baseline group, born 1936-1941), the 1998 War Babies (WB) group (born 1942-1947), the 2004 Early Baby Boomers (EBB) cohort (born 1948-1953), and the 2010 Middle Baby Boomer (MBB) group (born 1954-1959). The three 57-61 age cohorts of women were surveyed in 1992 for the baseline HRS cohort, in 2004 for the WB; and in 2010 for the EBB. Martial disruption defined as divorced/separated or widowed; All 1ry Res Loans/1ry Res Value is defined as the value of all primary residence loans divided by the value of the primary residence; and Other debt/liquid assets is defined as the ratio of other debt to liquid assets (excluding the home). See also Appendix 1. 
Table 2: Factors Associated with Older Women's Anticipated Future Work (HRS)

WB

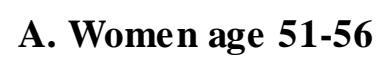

B. Women age 57-61

$-0.411$

$-0.433$

1.943

1.635

EBB

MBB

(1.515)

(1.515)

(1.422)

3.612 **

(1.850)

(1.851)

$5.138 * * *$

$4.708 * * *$

$7.900 * * *$

(1.420)

(1.693)

(1.692)

(1.413)

$7.666 * * *$

(1.414)

Age

-0.646 *

$-0.608 *$

(0.350)

(0.349)

White

$3.681 * * *$

$3.662 * * *$

(1.204)

(1.206)

Hispanic

2.984

2.926

(1.974)

(1.979)

$1.028 * * *$

$0.974 * * *$

Years of Education

$$
\text { (0.230) }
$$

(0.232)

Marital Disruption

Fair/Poor Health Self-reported

$$
9.523 * * *
$$

$9.652 * * *$

(1.305)

(1.306)

$-10.961 * * *$

$-10.971 * * *$

(1.388)

(1.387)

$-0.403$

$-0.430$

(0.322)

(0.322)

$-1.052 * \quad-1.008 *$

(0.563) (0.561)

Number of Children

All 1ry Res Loans/1ry Res. Value

$$
2.638 * *
$$

$4.243 * *$

$4.399 * * *$

(1.651)

(1.650)

$-0.671$

$-0.388$

(2.471)

(2.468)

$0.881 * * * \quad 0.885 * * *$

(0.308) (0.308)

$8.414 * * * \quad 8.498 * * *$

(1.687)

(1.687)

$-14.290 * * * \quad-14.035 * * *$

(1.775)

(1.774)

$-0.086$

$-0.140$

(0.393)

(0.394)

(1.038)

$2.283 * *$

(0.983)

0.058

Other debt/liquid assets

$0.014 *$

(0.008)

(0.058)

\begin{tabular}{lrr|rr}
\hline Intercept & $\begin{array}{c}40.493^{* *} \\
(18.957)\end{array}$ & $\begin{array}{r}38.445^{* *} \\
(18.931)\end{array}$ & $\begin{array}{c}70.029 \\
(33.179)\end{array}$ & $\begin{array}{r}66.865 \\
(33.069)\end{array}$ \\
\hline $\mathrm{N}$ & 5,152 & 5,152 & 2,976 & 2,976 \\
R-square & 0.060 & 0.062 & 0.063 & 0.065 \\
Mean of dep var & 26.289 & & 25.737 & \\
St.dev of dep var & 32.484 & & 33.338 & \\
\hline Mean of dep var, HRS only & 22.537 & & 23.379 & \\
St.dev of dep var, HRS only & 31.617 & & 32.773 & \\
\hline
\end{tabular}

Note: Question about the probability of working at 65 asked only of those working at survey date. See also Notes to Table 1. 
Table 3. Differences in Older Women's Debt by Type, by Cohort and Age Group (HRS)

\begin{tabular}{|c|c|c|c|c|c|c|c|c|c|}
\hline \multirow{2}{*}{\multicolumn{2}{|c|}{ 1. Have debt (0/1) }} & \multirow[t]{2}{*}{$\mathrm{p} 50$} & \multirow[t]{2}{*}{ Mean } & \multirow[t]{2}{*}{$\mathrm{N}$} & \multicolumn{3}{|c|}{ p50 } & Mean & \multirow[t]{2}{*}{$\mathrm{N}$} \\
\hline & & & & & \multicolumn{4}{|c|}{ 3. All 1ry Res Loans/1ry Res. Value $>0.5$} & \\
\hline \multirow[t]{4}{*}{ Age group $51-56$} & HRS & 0 & 0.42 & 2,806 & Age group 51-56 & HRS & 0 & 0.18 & 2,788 \\
\hline & WB & 0 & 0.41 & 847 & & WB & 0 & 0.24 & 839 \\
\hline & EBB & 0 & 0.44 & 1,207 & & EBB & 0 & 0.26 & 1,195 \\
\hline & MBB & 1 & 0.51 & 1,872 & & MBB & 0 & 0.32 & 1,860 \\
\hline \multirow[t]{3}{*}{ Age group 57-61 } & HRS & 0 & 0.37 & 2,056 & Age group 57-61 & HRS & 0 & 0.11 & 2,052 \\
\hline & WB & 0 & 0.39 & 699 & & WB & 0 & 0.22 & 690 \\
\hline & EBB & 0 & 0.44 & 1,424 & & EBB & 0 & 0.28 & 1,414 \\
\hline \multicolumn{5}{|c|}{ 2. Total debt (\$2015) } & \multicolumn{5}{|c|}{ 4. Have less than $\$ 25,000$ in savings } \\
\hline \multirow[t]{4}{*}{ Age group 51-56 } & HRS & 15,030 & 59,003 & 2,806 & Age group 51-56 & HRS & 0 & 0.18 & 2,806 \\
\hline & WB & 27,360 & 62,990 & 847 & & WB & 0 & 0.20 & 847 \\
\hline & EBB & 37,386 & 91,398 & 1,207 & & EBB & 0 & 0.23 & 1,207 \\
\hline & MBB & 43,200 & 98,210 & 1,872 & & MBB & 0 & 0.33 & 1,872 \\
\hline \multirow[t]{3}{*}{ Age group 57-61 } & HRS & 4,175 & 32,976 & 2,056 & Age group 57-61 & HRS & 0 & 0.16 & 2,056 \\
\hline & WB & 23,560 & 68,066 & 699 & & WB & 0 & 0.18 & 699 \\
\hline & EBB & 31,320 & 96,701 & 1,424 & & EBB & 0 & 0.26 & 1,424 \\
\hline
\end{tabular}

Note: Total debt includes the value of mortgages and other loans on the household's primary residence, other mortgages, and other debt (including credit card debt, medical debt, etc.). All dollar values in \$2015. Savings is defined as total net worth or total assets minus total debt. 
Table 4. Descriptive Statistics for Variables in the National Financial Capability Study (NFCS)

A. Women age 51-56 ( $\mathrm{N}=1844)$

\begin{tabular}{|c|c|c|c|c|c|}
\hline Variables & Mean & Median & Min & Max & SD \\
\hline Age & 53.54 & 54 & 51 & 56 & 1.72 \\
\hline Married & .61 & 1 & 0 & 1 & .49 \\
\hline Single & .12 & 0 & 0 & 1 & .32 \\
\hline Separated or divorced & .22 & 0 & 0 & 1 & .41 \\
\hline Widow & .05 & 0 & 0 & 1 & .22 \\
\hline White & .70 & 1 & 0 & 1 & .46 \\
\hline Black & .13 & 0 & 0 & 1 & .34 \\
\hline Hispanic & .11 & 0 & 0 & 1 & .31 \\
\hline Asian & .03 & 0 & 0 & 1 & .18 \\
\hline Other & .02 & 0 & 0 & 1 & .15 \\
\hline Education $<$ high school & .07 & 0 & 0 & 1 & .26 \\
\hline High school & .38 & 0 & 0 & 1 & .48 \\
\hline Some college & .32 & 0 & 0 & 1 & .46 \\
\hline College+ & .23 & 0 & 0 & 1 & .42 \\
\hline $\mathrm{N}$ dependent children & .58 & 0 & 0 & 4 & .92 \\
\hline Income $<\$ 15 \mathrm{~K}$ & .13 & 0 & 0 & 1 & .34 \\
\hline Income $\$ 15-25 \mathrm{~K}$ & .14 & 0 & 0 & 1 & .34 \\
\hline Income $\$ 25-35 \mathrm{~K}$ & .10 & 0 & 0 & 1 & .30 \\
\hline Income $\$ 35-50 \mathrm{~K}$ & .15 & 0 & 0 & 1 & .36 \\
\hline Income $\$ 50-75 \mathrm{~K}$ & .17 & 0 & 0 & 1 & .37 \\
\hline Income $\$ 75-100 \mathrm{~K}$ & .12 & 0 & 0 & 1 & .32 \\
\hline Income $\$ 100-150 \mathrm{~K}$ & .12 & 0 & 0 & 1 & .32 \\
\hline Income $>\$ 150 \mathrm{~K}$ & .07 & 0 & 0 & 1 & .25 \\
\hline Working & .51 & 1 & 0 & 1 & .50 \\
\hline Financial literacy (N correct answers) & 2.74 & 3 & 0 & 5 & 1.41 \\
\hline Income shock & .33 & 0 & 0 & 1 & .47 \\
\hline Retirement planning & .39 & 0 & 0 & 1 & .49 \\
\hline Having too much debt & .43 & 0 & 0 & 1 & .49 \\
\hline Financial fragility & .43 & 0 & 0 & 1 & .49 \\
\hline
\end{tabular}


B. Women age 57-61 ( $\mathrm{N}=1332)$

\begin{tabular}{|c|c|c|c|c|c|}
\hline Variables & Mean & Median & Min & Max & $\mathrm{SD}$ \\
\hline Age & 58.99 & 59 & 57 & 61 & 1.42 \\
\hline Married & .57 & 1 & 0 & 1 & .49 \\
\hline Single & .13 & 0 & 0 & 1 & .34 \\
\hline Separated or divorced & .22 & 0 & 0 & 1 & .41 \\
\hline Widow & .08 & 0 & 0 & 1 & .27 \\
\hline White & .69 & 1 & 0 & 1 & .46 \\
\hline Black & .18 & 0 & 0 & 1 & .38 \\
\hline Hispanic & .08 & 0 & 0 & 1 & .27 \\
\hline Asian & .03 & 0 & 0 & 1 & .19 \\
\hline Other & .02 & 0 & 0 & 1 & .14 \\
\hline Education $<$ high school & .06 & 0 & 0 & 1 & .24 \\
\hline High school & .37 & 0 & 0 & 1 & .48 \\
\hline Some college & .31 & 0 & 0 & 1 & .46 \\
\hline College or more & .25 & 0 & 0 & 1 & .43 \\
\hline $\mathrm{N}$ dependent children & .34 & 0 & 0 & 4 & .75 \\
\hline Income $<\$ 15 \mathrm{~K}$ & .11 & 0 & 0 & 1 & .31 \\
\hline Income $\$ 15-25 \mathrm{~K}$ & .13 & 0 & 0 & 1 & .33 \\
\hline Income $\$ 25-35 \mathrm{~K}$ & .16 & 0 & 0 & 1 & .36 \\
\hline Income $\$ 35-50 \mathrm{~K}$ & .15 & 0 & 0 & 1 & .36 \\
\hline Income $\$ 50-75 \mathrm{~K}$ & .18 & 0 & 0 & 1 & .38 \\
\hline Income $\$ 75-100 \mathrm{~K}$ & .09 & 0 & 0 & 1 & .29 \\
\hline Income $\$ 100-150 \mathrm{~K}$ & .10 & 0 & 0 & 1 & .30 \\
\hline Income $>\$ 150 \mathrm{~K}$ & .09 & 0 & 0 & 1 & .28 \\
\hline Working & .44 & 0 & 0 & 1 & .50 \\
\hline Financial literacy (N correct answers) & 2.79 & 3 & 0 & 5 & 1.40 \\
\hline Income shock & .30 & 0 & 0 & 1 & .46 \\
\hline Retirement planning & .45 & 0 & 0 & 1 & .50 \\
\hline Having too much debt & .39 & 0 & 0 & 1 & .49 \\
\hline Financial fragility & .39 & 0 & 0 & 1 & .49 \\
\hline
\end{tabular}

Note: The sample includes all age-eligible women age 51-56 and 57-61 in the 2012 NFCS. Financial literacy refers to the number of correct answers to 5 financial literacy questions. Income shock refers to a dummy variable for those who experience a large drop in income in the previous 12 months that they did not expect. Financial planning is coded as 1 for those who tried to figure out how much they need to save for retirement. Having too much debt refers to respondents who chose values 5, 6, or 7 (on a scale from 1 to 7) when asked to evaluate if they have too much debt. Financial fragility is coded as 1 for those who probably or certainly could not come up with $\$ 2,000$ within the next month. All statistics are weighted using survey weights. 
Table 5. Indicators of Financial Distress in the NFCS

A. Women age 51-56

\begin{tabular}{lcccccc} 
Variables & $\mathrm{N}$ & Mean & Median & Min & Max & SD \\
\hline Making ends meet & 1844 & .34 & 0 & 0 & 1 & .47 \\
Rainy day savings & 1844 & .34 & 0 & 0 & 1 & .47 \\
Underwater with home value & 886 & .20 & 0 & 0 & 1 & .40 \\
Credit card fees & 1303 & .41 & 0 & 0 & 1 & .49 \\
Loan on retirement accounts & 908 & .08 & 0 & 0 & 1 & .27 \\
Withdrawal from retirement & 908 & .05 & 0 & 0 & 1 & .22 \\
accounts & 1844 & .28 & 0 & 0 & 1 & .45 \\
Unpaid medical bills & 1800 & .25 & 0 & 0 & 1 & .43 \\
High-cost borrowing & & & & & &
\end{tabular}

B. Women age 57-61

\begin{tabular}{lcccccc} 
Variables & N & Mean & Median & Min & Max & SD \\
\hline Making ends meet & 1332 & .38 & 0 & 0 & 1 & .49 \\
Rainy day savings & 1332 & .41 & 0 & 0 & 1 & .49 \\
Underwater with home value & 606 & .15 & 0 & 0 & 1 & .35 \\
Credit card fees & 1004 & .38 & 0 & 0 & 1 & .48 \\
Loan on retirement accounts & 713 & .07 & 0 & 0 & 1 & .26 \\
Withdrawal from retirement & 713 & .05 & 0 & 0 & 1 & .23 \\
accounts & 1332 & .25 & 0 & 0 & 1 & .43 \\
Unpaid medical bills & 1309 & .22 & 0 & 0 & 1 & .41 \\
High-cost borrowing & & & & & &
\end{tabular}

Note: The sample includes all age-eligible women age 51-56 and 57-61 in the 2012 NFCS. Making ends meet refers to the ability to balance monthly income and expenses. Statistics related to underwater with home value and credit card fees are conditional on holding the asset or debt. Statistics related to loan on retirement accounts and hardship withdrawal from retirement accounts are conditional to having a retirement account. High-cost methods of borrowing refer to auto title loans, payday loans, pawn shops, rent-to-own stores, and tax refund loans. All statistics are weighted using survey weights. 
Table 6. Financial Literacy in the NFCS

\begin{tabular}{lcccc}
$\begin{array}{l}\text { A. Women age 51-56 } \\
\text { Questions }\end{array}$ & Correct & Incorrect & Don’t know & N \\
\hline Interest rate question & $72 \%$ & $15 \%$ & $12 \%$ & 1844 \\
Inflation question & $63 \%$ & $13 \%$ & $22 \%$ & 1844 \\
Risk diversification question & $42 \%$ & $5 \%$ & $52 \%$ & 1844 \\
Mortgage question & $74 \%$ & $10 \%$ & $16 \%$ & 1844 \\
Basic asset pricing question & $24 \%$ & $29 \%$ & $46 \%$ & 1844
\end{tabular}

\section{B. Women age $57-61$}

Questions

\begin{tabular}{cccc} 
Correct & Incorrect & Don’t know & $\mathrm{N}$ \\
\hline $71 \%$ & $17 \%$ & $11 \%$ & 1332 \\
$66 \%$ & $14 \%$ & $18 \%$ & 1332 \\
$41 \%$ & $6 \%$ & $51 \%$ & 1332 \\
$76 \%$ & $7 \%$ & $15 \%$ & 1332 \\
$24 \%$ & $29 \%$ & $45 \%$ & 1332
\end{tabular}

Note: The sample includes all age-eligible women age 51-56 and 57-61 in the 2012 NFCS. All statistics are weighted using survey weights. 
Table 7. Determinants of Having Tried to Figure Out How Much to Save for Retirement, Having Too Much Debt, and Not Being Able to Come Up with \$2,000 (NFCS)

\section{A. Women age 51-56}

(1) Retirement planning Having too much debt Financial fragility

(3)

Variables

\begin{tabular}{|c|c|c|c|}
\hline Age & $\begin{array}{c}0.004 \\
(0.006)\end{array}$ & $\begin{array}{l}-0.008 \\
(0.030)\end{array}$ & $\begin{array}{l}-0.006 \\
(0.006)\end{array}$ \\
\hline \multirow[t]{2}{*}{ Black } & -0.021 & $0.453 * * *$ & $0.099 * * *$ \\
\hline & $(0.033)$ & $(0.159)$ & $(0.030)$ \\
\hline \multirow[t]{2}{*}{ Hispanic } & $-0.068 * *$ & $-0.456^{* * *}$ & -0.010 \\
\hline & $(0.034)$ & $(0.164)$ & $(0.032)$ \\
\hline \multirow[t]{2}{*}{ Asian } & -0.050 & -0.397 & -0.070 \\
\hline & $(0.058)$ & $(0.284)$ & $(0.054)$ \\
\hline \multirow[t]{2}{*}{ Others } & -0.063 & -0.193 & -0.039 \\
\hline & $(0.068)$ & $(0.328)$ & $(0.063)$ \\
\hline \multirow[t]{2}{*}{ Single } & $0.079 * *$ & -0.197 & $-0.063^{*}$ \\
\hline & $(0.035)$ & (0.174) & $(0.033)$ \\
\hline \multirow[t]{2}{*}{ Separated or divorced } & 0.011 & $-0.237 *$ & 0.005 \\
\hline & $(0.029)$ & $(0.140)$ & $(0.027)$ \\
\hline \multirow{2}{*}{ Widow } & 0.029 & 0.022 & $-0.126 * * *$ \\
\hline & $(0.050)$ & $(0.239)$ & $(0.046)$ \\
\hline \multirow[t]{2}{*}{ Number of dependent children } & $-0.027 * *$ & $0.121^{* *}$ & $0.023^{* *}$ \\
\hline & $(0.012)$ & $(0.056)$ & $(0.011)$ \\
\hline \multirow{2}{*}{ High school } & 0.046 & -0.042 & $0.107^{* * *}$ \\
\hline & $(0.042)$ & $(0.212)$ & $(0.039)$ \\
\hline \multirow[t]{2}{*}{ Some college } & $0.148 * * *$ & 0.169 & 0.034 \\
\hline & $(0.044)$ & $(0.221)$ & $(0.041)$ \\
\hline \multirow[t]{2}{*}{ College+ +} & $0.191^{* * *}$ & 0.152 & 0.058 \\
\hline & $(0.048)$ & $(0.238)$ & $(0.045)$ \\
\hline \multirow[t]{2}{*}{$\$ 15-25 K$} & $0.098 * *$ & -0.038 & $-0.155^{* * *}$ \\
\hline & $(0.040)$ & $(0.197)$ & $(0.037)$ \\
\hline \multirow[t]{2}{*}{$\$ 25-35 K$} & $0.097 * *$ & -0.161 & $-0.195 * * *$ \\
\hline & $(0.044)$ & $(0.213)$ & $(0.040)$ \\
\hline \multirow[t]{2}{*}{$\$ 35-50 \mathrm{~K}$} & $0.130 * * *$ & -0.179 & $-0.364 * * *$ \\
\hline & $(0.041)$ & $(0.200)$ & $(0.038)$ \\
\hline \multirow[t]{2}{*}{$\$ 50-75 \mathrm{~K}$} & $0.227 * * *$ & -0.072 & $-0.485 * * *$ \\
\hline & $(0.042)$ & $(0.206)$ & $(0.039)$ \\
\hline \multirow[t]{2}{*}{$\$ 75-100 \mathrm{~K}$} & $0.264 * * *$ & -0.319 & $-0.535 * * *$ \\
\hline & $(0.046)$ & $(0.226)$ & $(0.043)$ \\
\hline \multirow{2}{*}{$\$ 100-150 K$} & $0.365 * * *$ & $-0.693^{* * *}$ & $-0.677 * * *$ \\
\hline & $(0.048)$ & $(0.236)$ & $(0.044)$ \\
\hline \multirow{2}{*}{$\$ 150 \mathrm{~K}+$} & $0.440^{* * *}$ & $-1.293 * * *$ & $-0.724 * * *$ \\
\hline & $(0.056)$ & $(0.275)$ & $(0.052)$ \\
\hline \multirow[t]{2}{*}{ Income shock } & -0.025 & $0.779 * * *$ & $0.205^{* * *}$ \\
\hline & $(0.022)$ & $(0.109)$ & $(0.021)$ \\
\hline \multirow{2}{*}{$\mathrm{N}$ correct answers finlit questions } & $0.061 * * *$ & $-0.105^{* *}$ & $-0.021 * * *$ \\
\hline & $(0.008)$ & $(0.042)$ & $(0.008)$ \\
\hline \multirow[t]{2}{*}{ Constant } & -0.253 & $4.834 * * *$ & $1.041^{* * *}$ \\
\hline & $(0.330)$ & $(1.601)$ & $(0.306)$ \\
\hline Observations & 1,844 & 1,813 & 1,844 \\
\hline R-squared & 0.194 & 0.082 & 0.326 \\
\hline
\end{tabular}




\section{B. Women age 57-61}

(1) (2) (3)

Variables

Retirement planning Having too much debt

Financial fragility

\begin{tabular}{|c|c|c|c|}
\hline Age & $\begin{array}{c}0.023^{* *} \\
(0.009)\end{array}$ & $\begin{array}{l}-0.075 * \\
(0.042)\end{array}$ & $\begin{array}{c}0.002 \\
(0.008)\end{array}$ \\
\hline \multirow[t]{2}{*}{ Black } & 0.001 & 0.080 & $0.116^{* * *}$ \\
\hline & $(0.036)$ & $(0.167)$ & $(0.032)$ \\
\hline \multirow[t]{2}{*}{ Hispanic } & 0.009 & 0.086 & $0.160 * * *$ \\
\hline & $(0.049)$ & $(0.228)$ & $(0.043)$ \\
\hline \multirow[t]{2}{*}{ Asian } & -0.064 & 0.187 & $0.122 * *$ \\
\hline & $(0.070)$ & $(0.332)$ & $(0.062)$ \\
\hline \multirow[t]{2}{*}{ Others } & -0.025 & 0.018 & 0.101 \\
\hline & (0.091) & $(0.426)$ & $(0.081)$ \\
\hline \multirow{2}{*}{ Single } & -0.052 & $0.513^{* * *}$ & -0.013 \\
\hline & $(0.043)$ & $(0.198)$ & (0.038) \\
\hline \multirow[t]{2}{*}{ Separated or divorced } & -0.032 & $0.304^{*}$ & 0.040 \\
\hline & $(0.036)$ & $(0.165)$ & (0.032) \\
\hline \multirow[t]{2}{*}{ Widow } & 0.049 & $0.675 * * *$ & 0.065 \\
\hline & $(0.050)$ & $(0.231)$ & $(0.044)$ \\
\hline \multirow[t]{2}{*}{ Number of dependent children } & -0.024 & $0.330 * * *$ & $0.034 * *$ \\
\hline & $(0.017)$ & $(0.079)$ & $(0.015)$ \\
\hline \multirow[t]{2}{*}{ High school } & $0.098 *$ & -0.182 & $-0.159 * * *$ \\
\hline & $(0.057)$ & $(0.262)$ & $(0.050)$ \\
\hline \multirow[t]{2}{*}{ Some college } & $0.151^{* *}$ & -0.269 & $-0.202 * * *$ \\
\hline & $(0.059)$ & $(0.274)$ & $(0.053)$ \\
\hline \multirow[t]{2}{*}{ College+ } & $0.225 * * *$ & -0.370 & $-0.201^{* * *}$ \\
\hline & $(0.064)$ & $(0.295)$ & $(0.057)$ \\
\hline \multirow[t]{2}{*}{$\$ 15-25 K$} & $0.087^{*}$ & 0.250 & $-0.092 * *$ \\
\hline & $(0.053)$ & $(0.242)$ & $(0.047)$ \\
\hline \multirow[t]{2}{*}{$\$ 25-35 K$} & $0.212^{* * *}$ & -0.078 & $-0.224 * * *$ \\
\hline & $(0.051)$ & $(0.238)$ & $(0.045)$ \\
\hline \multirow[t]{2}{*}{$\$ 35-50 \mathrm{~K}$} & $0.204^{* * *}$ & -0.116 & $-0.360 * * *$ \\
\hline & $(0.052)$ & $(0.242)$ & $(0.047)$ \\
\hline \multirow[t]{2}{*}{$\$ 50-75 \mathrm{~K}$} & $0.251^{* * *}$ & -0.173 & $-0.443 * * *$ \\
\hline & $(0.053)$ & $(0.244)$ & $(0.047)$ \\
\hline \multirow[t]{2}{*}{$\$ 75-100 \mathrm{~K}$} & $0.259 * * *$ & -0.356 & $-0.504 * * *$ \\
\hline & $(0.062)$ & $(0.290)$ & $(0.055)$ \\
\hline \multirow[t]{2}{*}{$\$ 100-150 \mathrm{~K}$} & $0.373 * * *$ & 0.017 & $-0.607 * * *$ \\
\hline & $(0.064)$ & $(0.299)$ & $(0.057)$ \\
\hline \multirow[t]{2}{*}{$\$ 150 \mathrm{~K}+$} & $0.469 * * *$ & $-0.845^{* * *}$ & $-0.590 * * *$ \\
\hline & $(0.066)$ & $(0.306)$ & (0.059) \\
\hline \multirow[t]{2}{*}{ Income shock } & $0.050 *$ & $0.685^{* * *}$ & $0.153^{* * *}$ \\
\hline & $(0.028)$ & $(0.131)$ & $(0.025)$ \\
\hline \multirow[t]{2}{*}{$\mathrm{N}$ correct answers finlit questions } & $0.044 * * *$ & $-0.083^{*}$ & $-0.029 * * *$ \\
\hline & $(0.010)$ & $(0.049)$ & (0.009) \\
\hline \multirow{2}{*}{ Constant } & $-1.398 * * *$ & $8.394 * * *$ & 0.760 \\
\hline & $(0.541)$ & $(2.494)$ & $(0.480)$ \\
\hline Observations & 1,332 & 1,312 & 1,332 \\
\hline R-squared & 0.153 & 0.087 & 0.307 \\
\hline
\end{tabular}

Note: Coefficient estimates from analysis reported in the text, standard errors in parentheses. Retirement planning coded as 1 for those who tried to figure out how much they need to save for retirement. Having too much debt ranges from 1 to 7, where 1 means I strongly disagree and 7 I strongly agree with the statement "I have too

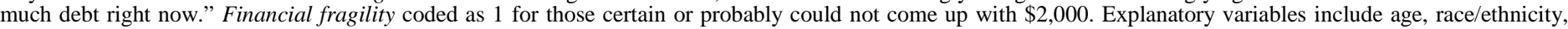

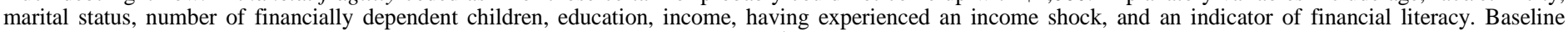
categories: White, married, less than high school education, and income lower than $\$ 15,000$. Weighted data. $* * * p<0.01, * * p<0.05$, $* \mathrm{p}<0.1$ 
Figure 1. Longitudinal Data Design of HRS

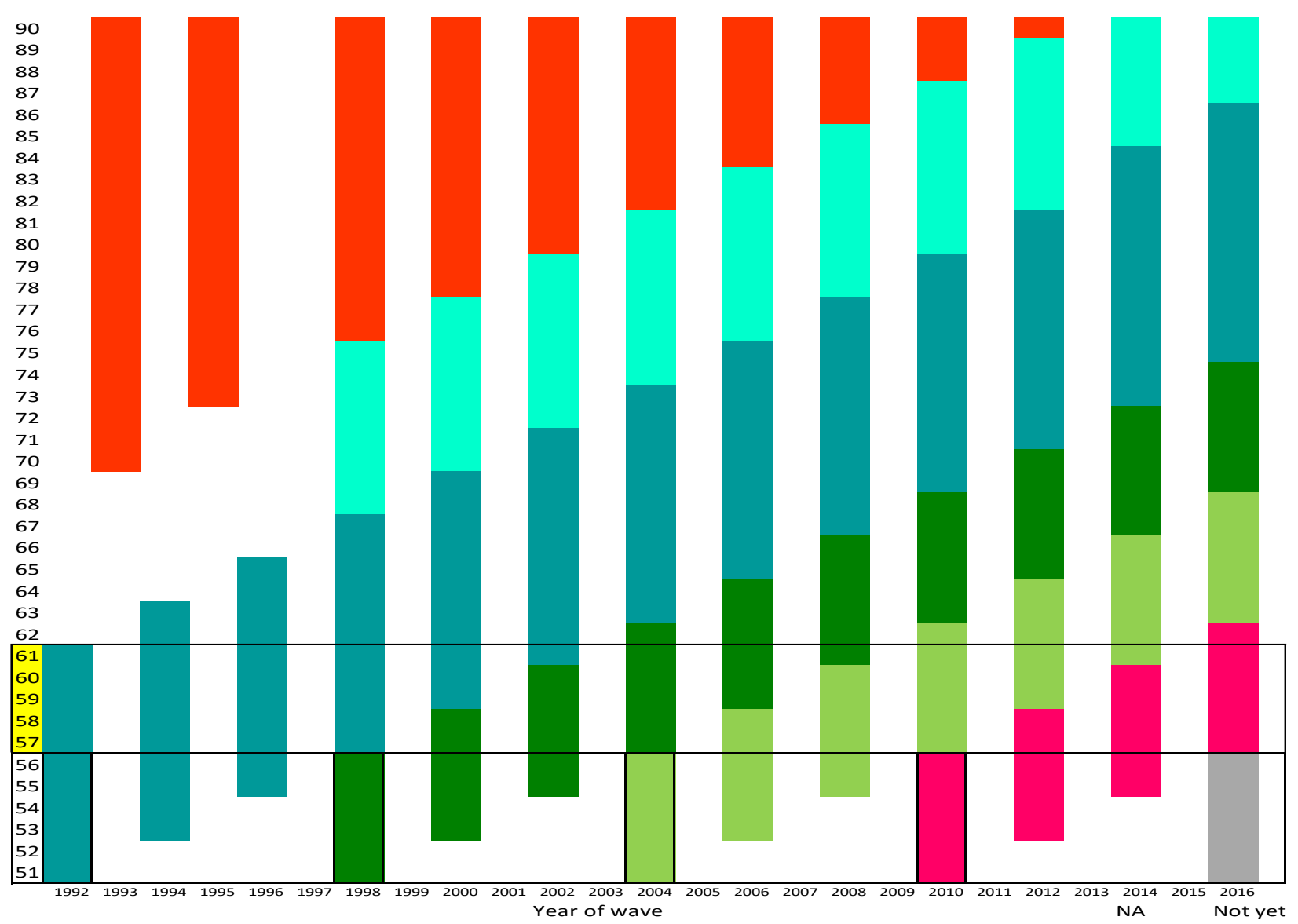

\footnotetext{
Ahead

CODA

WBB

EBB

MBB

LBB
}

HRS Original 


\section{Appendix 1. Descriptive Statistics for HRS women}

Variables

Working for pay

Prob. Working at 65 (\%)

Age

White

Hispanic

Years of Education

Fair/Poor Health self-reported

Marital disruption

Number of children

All 1ry Res Loans/1ry Res. Value

Other debt/liquid assets

HRS

WB

EBB

MBB

\begin{tabular}{|c|c|c|c|}
\hline \multicolumn{4}{|c|}{ Women Age 51-56 Women Age 57-61 } \\
\hline Mean & $S D$ & N Mean & $S D$ \\
\hline 0.71 & 0.45 & 0.61 & 0.49 \\
\hline 26.29 & 32.48 & 25.74 & 33.34 \\
\hline 53.16 & 1.61 & 58.82 & 1.41 \\
\hline 0.80 & 0.40 & 0.82 & 0.39 \\
\hline 0.09 & 0.29 & 0.08 & 0.28 \\
\hline 13.15 & 2.82 & 12.94 & 2.99 \\
\hline 0.23 & 0.42 & 0.25 & 0.43 \\
\hline 0.28 & 0.45 & 0.31 & 0.46 \\
\hline 2.65 & 1.77 & 2.82 & 1.92 \\
\hline 0.30 & 0.54 & 0.25 & 0.62 \\
\hline 2.12 & 41.57 & 0.77 & 8.12 \\
\hline 0.23 & 0.42 & 0.29 & 0.46 \\
\hline 0.21 & 0.41 & 0.32 & 0.47 \\
\hline 0.25 & 0.43 & 0.39 & 0.49 \\
\hline 0.31 & 0.46 & 0.00 & 0.00 \\
\hline
\end{tabular}

